\title{
EFEK EKSTRAK ETANOL RIMPANG TEMULAWAK (Curcuma xanthorrhiza Roxb) TERHADAP MEMORI SPASIAL TIKUS MODEL DEMENSIA YANG DIINDUKSI TRIMETHYLTIN
}

\section{THE EFFECT OF Curcuma xanthorrhiza Roxb RHIZOME ETHANOL EXTRACT TO SPATIAL MEMORY ON DEMENTIA RATS INDUCED BY TRIMETHYLTIN}

\author{
Nuroh Aspamufita, Sapto Yuliani \\ Fakultas Farmasi Universitas Ahmad Dahlan, Yogyakarta \\ Jl. Prof. Dr. Supomo, Telp. (0274) 379418 \\ Email : syuliani@yahoo.com
}

\begin{abstract}
Abstrak
Temulawak (Curcuma xanthorrhiza Roxb) merupakan salah satu tanaman yang mengandung kurkumin. Kurkumin telah terbukti berkhasiat sebagai anti amyloidogenic, antioksidan, dan anti inflamasi yang dapat mencegah demensia. Penelitian ini bertujuan untuk mengetahui efek ekstrak etanol rimpang temulawak (Curcuma xanthorrhiza Roxb) terhadap memori spasial tikus model demensia yang diinduksi trimethyltin (TMT). Penelitian ini menggunakan 30 ekor tikus yang terbagi menjadi 6 kelompok, masing-masing kelompok terdiri dari 5 ekor tikus. Semua kelompok diberi TMT secara intraperitoneal kecuali kelompok I. Kelompok I (kontrol sehat) dan kelompok II (kontrol TMT/sakit) diberi larutan CMC-Na 1\% secara oral. Kelompok III (kontrol obat) diberi larutan citicoline dengan dosis $200 \mathrm{mg} / \mathrm{kgBB}$. Kelompok IV,V, dan VI diberi ekstrak temulawak dengan dosis masing-masing $50 \mathrm{mg} / \mathrm{kgBB}, 100 \mathrm{mg} / \mathrm{kgBB}$, dan $150 \mathrm{mg} / \mathrm{kgBB}$ secara oral. Gambaran memori spasial diperoleh melalui uji Morris water maze yang terdiri dari acquisition trial dan probe trial. Data hasil uji kemudian dianalisa secara statistik dengan one-way repeated measure ANOVA.Hasil uji Morris water maze menunjukkan bahwa terdapat perbedaan bermakna antara kontrol sakit dibandingkan dengan kelompok perlakuan ekstrak temulawak dosis $50 \mathrm{mg} / \mathrm{kgBB}, 100 \mathrm{mg} / \mathrm{kgBB}$ dan $150 \mathrm{mg} / \mathrm{kgBB}(\mathrm{p}<0,05)$. Tidak terdapat perbedaan bermakna antara ekstrak temulawak dosis $100 \mathrm{mg} / \mathrm{kgBB}$ dengan kontrol sehat $(\mathrm{p}>0,05)$. Berdasarkan hasil penelitian dapat disimpulkan bahwa ekstrak etanol rimpang temulawak Curcuma xanthorrhiza Roxb pada dosis $100 \mathrm{mg} / \mathrm{kgBB}$ dapat meningkatkan memori spasial pada tikus model demensia yang diinduksi TMT.
\end{abstract}

Kata kunci : Curcuma xanthorrhiza Roxb, memori spasial, Morris water maze 


\begin{abstract}
Curcuma xanthorrhiza Roxb is one of the plants containing curcumin. Curcumin has anti-amyloidogenic, antioxidant, and anti-inflammatory activity that can prevent dementia. The aim of the research was to know the effect of Curcuma xanthorrhiza Roxb rhizome ethanol extract (CREE) to spatial memory on dementia model rat induced by trimethyltin (TMT). This research use 30 rats, divided into 6 groups, each group consisted of 5 rats. All groupswere given trimethyltin intraperitoneal lyexcep tgroup I.Group I (healthy controls) and group II (TMT /illness control) were given a solution of 1\% CMC-Na orally. Group III (drug control) were given citicoline 200 $\mathrm{mg} / \mathrm{kgBW}$ orally. Group IV, V, and VI were given CREE orally dose $50 \mathrm{mg} / \mathrm{kgBW}, 100 \mathrm{mg} / \mathrm{kgBW}$, and 150 $\mathrm{mg} / \mathrm{kgBW}$ respectively. Data of spatial memory were obtained by Morris water maze test consisted of acquisition trial, and a probe trial. Data from the test then statistically analyzed by one-way repeated measure ANOVA. Morris water maze test showed that there were significant differences $(p<0,05)$ between TMT group compared with CREE dose $50 \mathrm{mg} / \mathrm{kgBW}, 100 \mathrm{mg} / \mathrm{kgBW}$, and $150 \mathrm{mg} / \mathrm{kgBW}$ group. But there was no significant difference $(\mathrm{p}>0,05)$ between CREE dose $100 \mathrm{mg} / \mathrm{kgBW}$ group anddrug control group.Based on the research results can be concluded that ethanol extract Curcuma xanthorrhiza Roxb rhizome at dose of $100 \mathrm{mg} / \mathrm{kgBW}$ can improve spatial memory on dementia model rat induced by trimethyltin.
\end{abstract}

Key word s : Curcuma xanthorrhiza Roxb., spatial memory, Morris water maze

\section{PENDAHULUAN}

Demensia adalah penurunan yang progresif terhadap fungsi kognitif, tingkah laku dan kepribadian akibat penyakit pada sebagian atau seluruh hemisfer cerebri. Demensia menyebabkan gangguan fungsi memori tanpa adanya gangguan kesadaran (Evans et al., 2000). Alzheimer's disease adalah tipe demensia dengan persentase kasus terbanyak, $60 \%$ dari semua kasus demensia (Van Marum, 2008).

Stres oksidatif merupakan pato-genesis penting demensia (Butterfield et al. 2002). Trimethyltin (TMT) merupakan senyawa organometal yang bersifat neurotoksik dan dapat menyebabkan kematian sarafpada otak tikus melalui mekanisme stres oksidatif (Shuto et al. 2009). Neurode generasi ditandai dengan kematian saraf terutama pada daerah sistem limbic dan hipokampus pada khususnya (Geloso et al. 2004). Induksi TMT biasa digunakan sebagai model demensia tipe Alzheimer (Ishikawa et al. 1997) karena TMT menyebabkan gangguan proses memori (Geloso et al. 2004). TMT menyebabkan penurunan kemampuan tikus pada Morris water maze (MWM) karena adanya neuro-degenerasi pada hipokampus (Park et al. 2011).

Uji MWM akan menggambarkan memori spasial pada tikus. Memori spasial pada binatang berperan dalam menemukan lokasi yang menyediakan makanan dan keselamatan untuk mempertahankan hidup (Dogru et al. 2003). Memori spasial binatang sama dengan memori deklaratif pada manusia. Memori deklaratif adalah memori tentang suatu objek yang berhubungan dengan lingkungan sekitarnya (Guyton dan Hall, 2000).
Zat antioksi dan dapat mencegah dan memperbaiki kerusakan akibat stres oksidatif. Cole et al. (2004) menyatakan kurkumin dapat menunda dan mencegah progresifitas Alzheimer's disease. Temulawak Curcuma xanthorrhiza Roxb merupakan salah satu tanaman asli Indonesia yang dapat dimanfaatkan sebagai obat alternatif karena di dalam rimpangnya mengandung senyawa kurkumin.

Percobaan secara in vitro dan in vivo membuktikan bahwa kurkumin berkhasiat sebagai anti amyloidogenic, antioksidan, dan anti inflamasi yang dapat mencegah Alzheimer's disease (Ringman et al. 2005). Bahkan sifat antioksidan kurkumin sepuluh kali lebih kuat dibandingkan vitamin $\mathrm{E}$ (Khopde et al. 1999).

Penelitian ini bertujuan untuk mengetahui efek ekstrak etanol rimpang temulawak Curcuma xanthorrhiza Roxb terhadap memori spatial tikus model demensia yang diinduksi TMT. Penelitian ini diharapkan akan menjadi dasar pengembangan temulawak sebagai anti demensia.

\section{METODE PENELITIAN}

Alat

Alat yang digunakan yaitu alat- alat gelas pyrex, magnetics tirrer, rotary evaporator Heidolph, timbangan Ohauss, tabung reaksi, chamber, densitometer. Alat untuk uji memori adalah kolam Morris water maze, video camera, kain, hair dryer, dan spuit injeksi. 


\section{Bahan}

Bahan uji yang digunakan adalah rimpang temulawak yang diperoleh dari CV. Merapi Farma di daerah Sleman, etanol 96\%, tikus jantan galur Sprague-Dawley dengan berat badan 150-250 gramberumur 2-3 bulan yang diperoleh dari UPHP Universitas Gadjah Mada, Yogyakarta. Bahan standarisasi ekstrak yaitu silica gel 60 F 254 sebagai fase diam dan fase gerak kloroform dan metanol proanalisi. Bahan kimia yang digunakan yaitu trimethyltin chloride sebagai induktor model demensia, citicoline sebagai obat pembanding, $\mathrm{NaCl}$ 0,9\% sebagai pelarut TMT, aquades sebagai pelarut citicoline, $\mathrm{CMC} \mathrm{Na}$ 1\% sebagai pelarut ekstrak. Bahan untuk uji MWM adalah air dan santan.

\section{Pembuatan Ekstrak}

Serbuk rimpang temulawak diidentifikasi di Laboratorium Biologi Fakultas MIPA Universitas Ahmad Dahlan. 250 gram serbuk kemudian dimaserasi kemudian dimasukkan dalam gelas beker $1000 \mathrm{ml}$ dan direndam $500 \mathrm{ml}$ etanol $96 \%$ selama 24 jam. Sebelumnya dilakukan pengadukan dengan magnetic stirrer selama 2 jam. Maserat kemudian disaring dengan corong Buchner sampai terpisah dari ampasnya. Sari etanol kemudian diuapkan dengan rotary evaporator hingga terbentuk ekstrak kental.

\section{Standarisasi Ekstrak}

Membuat larutan induk kurkumin $50 \mathrm{mg} / \mathrm{ml}$. Kemudian membuat kurva baku $(1 ; 5 ; 10 ; 15 ; 20 ; 25 ; 30$ $\mathrm{mg} / \mathrm{ml}$ ) dan larutan sampel dengan melarutkan 100 mg ekstrak ke dalam $10 \mathrm{ml}$ etanol 96\%. Dengan fase diam silica gel 60 F 254 dan fase gerak campuran kloroform dan methanol (9:1) plate KLT dielusi kemudian dibaca menggunakan densitometer.

\section{Jalannya Penelitian}

30 ekor hewan uji dibagi menjadi 6 kelompok. Semua kelompok kecuali kelompok I (kontrol sehat) diberi induksi larutan TMT dosis $8 \mathrm{mg} / \mathrm{kg} \mathrm{BB}$. Kelompok I (kontrol sehat) dan kelompok II (kontrol sakit) diberi larutan $\mathrm{CMC} \mathrm{Na} \mathrm{1 \%} \mathrm{secara} \mathrm{peroral.}$ Kelompok III (kontrol obat) diberi larutan citicoline dengan dosis $200 \mathrm{mg} / \mathrm{kg}$ BB. Kelompok IV, V, IV diberi suspensi ekstrak etanol rimpang temulawak dengan dosis $50 \mathrm{mg} / \mathrm{kg} \mathrm{BB} ; 100 \mathrm{mg} / \mathrm{kg} \mathrm{BB} ; 150$ $\mathrm{mg} / \mathrm{kg}$ BB. Perlakuan dilakukan selama 21 hari dan hari ke-22 dilakukan uji Morris water maze.

\section{Uji Morris Water Maze (MWM)}

Uji Morris water maze dilakukan sesuai metode yang dilakukan oleh Vorhees dan Williams (2006) dengan modifikasi Pengujian terdiri dari 3 tahapan yaitu acquisition trial, probe trial dan uji kemampuan sensorimotoris. Kolam dibagi menjadi empat kuadran secara imaginer dan di sekeliling maze diberi penanda berupa poster, pintu, sumber cahaya dan pengamat. Kamera video diletakkan di atas maze. Kolam diisi air opak dengan diberi santan.

Acquisition trial dilakukan selama 5 hari. Tikus akan dilatih untuk menemukan platform yang terletak $2 \mathrm{~cm}$ di bawah permukaan air pada salah satu kuadran sebanyak empat kali per hari. Tikus dimasukan ke dalam kolam pada salah satu kuadran secara random. Waktu diakhiri jika tikus telah mencapai platform atau setelah berenang selama 60 detik tetapi belum mencapai platform. Jika tikus tidak berhasil menemukan platform selama 60 detik maka tikus akan dibimbing untuk menemukan platform dan ditempatkan di atas platform selama 15 detik sebelum latihan berikutnya. Waktu dan jarak tempuh tikus mencapai platform dicatat.

Pada probe trial tikus dibiarkan berenang selama 60 detik tanpa platform. Kemudian dilakukan pencatatan terhadap waktu lamanya tikus berada di kuadran letak platform dan berapa kali tikus melintasi kuadran letak platform, hal ini juga dilakukan sebanyak empat kali tiap tikus.

Pada uji kemampuan sensori-motoris, platform terletak $2 \mathrm{~cm}$ di bawah air diberi penanda dengan warna mencolok. Letak platform diubah-ubah pada kuadran yang berbeda tiap latihan. Tikus dimasukan pada salah satu kuadran kecuali pada kuadran yang ditempati platform. Tiap tikus dilatih empat kali, jika selama 60 detik tikus tidak dapat mencapai platform maka tikus akan dibimbing untuk menemukan platform. Waktu tempuh tikus untuk menemukan platform dicatat.

\section{Analisis Data}

Data Acquisition trial dan probe trial dianalisa secara ststistik menggunakan uji one-wayrepeated measure ANOVA dan dilanjutkan dengan uji LSD dengan taraf kepercayaan 95\%.

Data jarak diperoleh menggunakan curvemeter, dan dihitung menggunakan rumus berikut :

$=\frac{\text { diameter kolam sebenarnya }}{\text { diameter kolam pada video }} \times$ jarak pada video

\section{HASIL DAN PEMBAHASAN}

\section{Pembuatan ekstrak}

Hasil identifikasi simplisia menunjukan bahwa simplisia yang digunakan dalam penelitian ini adalah benar simplisia rimpang temulawak Curcuma 
xanthorrhiza Roxb).Ekstrak kental etanol rimpang temulawak yang diperoleh sebanyak 86,85 gram atau $8,69 \%$. Hasil standarisasi menunjukkan bahwa kurkumin yang terkandung dalam ekstrak sebesar $95,73 \%$.

\section{Hasil Uji Morris Water Maze}

Uji Morris water maze (MWM) terdiri dari tiga tahap yaitu, acquisition trial, probe trial, dan uji kemampuan sensorimotoris. Gambaran memori spasial akan diperoleh dari Acquisition trial dan probe trial.

Acquisition trial adalah tes untuk melihat fase latihan sebagai proses pembelajaran untuk pembentukan memori spasial. Fase ini dilakukan dalam 5 hari berturut-turut dengan 4 latihan per hari. Hasil acquisition trial dapat dilihat pada Gambar 1 dan 2 .

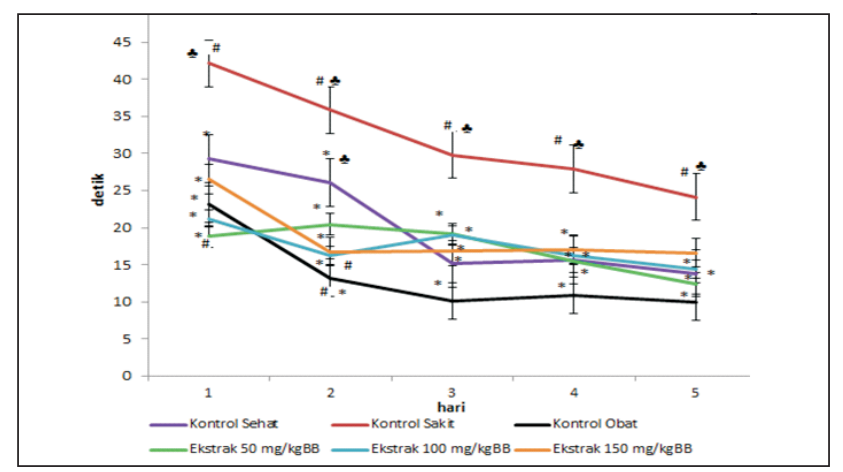

Gambar 1. Rerata waktu latensi \pm SEM pada Acquisition trial. Pengujian dilakukan selama 5 hari dengan 4 kali latihan perhari. * menunjukan $\mathrm{p}=<\mathbf{0 , 0 5}$ jika dibandingkan kontrol sakit, \# jika dibandingkan kontrol sehat, dan * jika dibandingkan kontrol obat

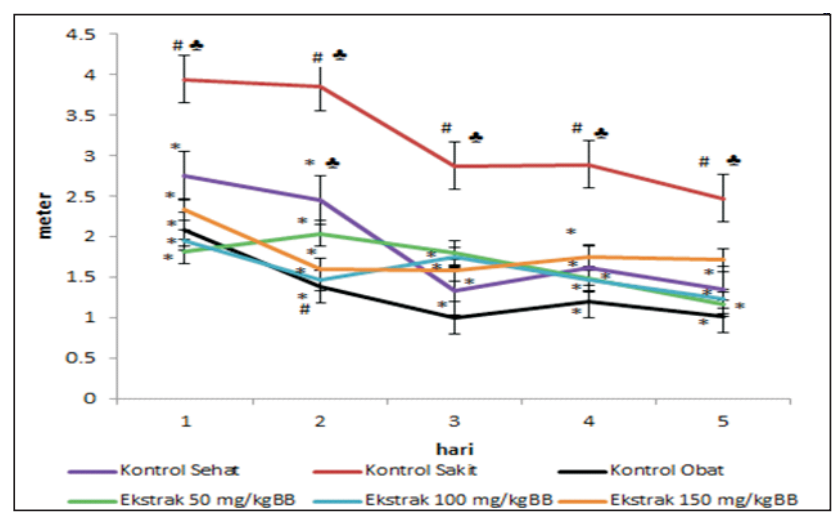

Gambar 2. Rerata jarak \pm SEM pada Acquisition trial. Pengujian dilakukan selama 5 hari dengan 4 kali latihan perhari. * menunjukan $\mathrm{p}=<\mathbf{0 , 0 5}$ jika dibandingkan kontrol sakit, \# jika dibandingkan kontrol sehat, dan \& jika dibandingkan kontrol obat
Gambar 1 dan 2 menunjukan pemberian TMT dapat menurunkan fungsi memori. Seperti yang dinyatakan oleh Balaban et al. (1988) bahwa pemberian TMT dapat menyebabkan terjadinya penurunan fungsi memori dan penurunan kemampuan belajar karena terjadinya neurode- generasi pada hipokampus. Neurode generasi terjadi karena TMT akan menyebabkan stres oksidatif dengan memproduksi reactive oxygen species (ROS), meningkatkan reactive nitrogen species (RNS) dan peroksidasi lipid (Zhang et al., 2006).

Pada data waktu jika kelompok kontrol sehat dibandingkan dengan kelompok ekstrak, hanya kelompok ekstrak dengan dosis $150 \mathrm{mg} / \mathrm{kgBB}$ yang menunjukan tidak ada perbedaan yang bermakna (lihat Gambar 1). Kelompok ekstrak dosis 50 $\mathrm{mg} / \mathrm{kgBB}$ menunjukan perbedaan bermakna pada hari ke-1. Kelompok ekstrak dosis $100 \mathrm{mg} / \mathrm{kgBB}$ menunjukan perbedaan bermakna pada hari ke-2.

Pada data jarak tidak ada perbedaan yang bermakna pada semua kelompok ekstrak, baik dosis 50; 100; maupun 150 mg/kgBB (lihat Gambar 2). Hal ini menunjukan bahwa sebenarnya pemberian ekstrak etanol rimpang temulawak dapat meningkatkan memori spasial pada tikus model demensia yang diinduksi TMT dengan adanya kandungan kurkumin yang berkhasiat sebagai zat antioksidan sehingga dapat mencegah terjadinya neurodegenerasi. Kandungan kurkumin dalam ekstrak etanol rimpang temulawak kemungkinan dapat mencegah terjadinya stres oksidatif akibat induksi TMT dengan menurunkan terbentuknya reactive oxygen species (ROS) dan reactive nitrogen species (RNS) serta mencegah terjadinya peroksidasi lipid. Seperti hasil penelitian Ringman et al. (2005), kurkumin berkhasiat sebagai antioksidan dengan cara mencegah terbentuknya radikal bebas dan menurunkan peroksidasi lipid. Selain itu, kurkumin sebagai antioksidan juga dapat serta meningkatkan aktivitas super oxide dismutase (SOD) dan sodium-potassium ATPase yang normalnya akan menurun dengan bertambahnya usia (Bala et al., 2006).

Probe trial adalah tes untuk melihat fungsi memori hewan uji yaitu kemampuan penyimpanan memori spasial setelah fase pembelajaran pada acquisition trial. Probe trialdilakukan selama satu hari dengan empat kali tes. Hasil probe trial dapat dilihat pada Gambar 3 dan 4 .

Dari Gambar 3 dan 4 dapat diketahui bahwa pemberian TMT menyebabkan terjadinya gangguan pada fungsi memori. Selain itu dapat diketahui bahwa pemberian citicoline sebagai obat pembanding dapat meningkatkan fungsi memori tikus model demensia yang diinduksi TMT.Sesuai dengan hasil penelitian 


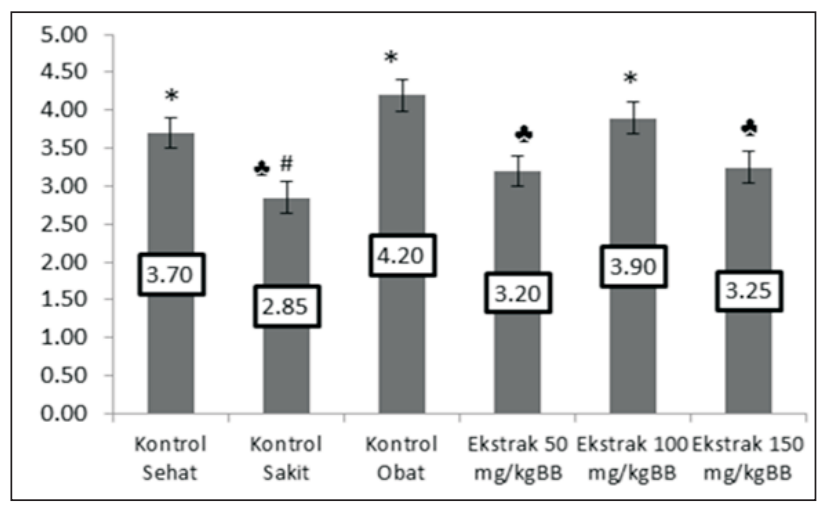

Gambar 3. Rerata berapa kali tikus di kuadran platform \pm SEM pada probe trial.* menunjukan $p=<0,05$ jika dibandingkan kontrol sakit, \# jika dibandingkan kontrol sehat, * jika dibandingkan kontrol obat, dan • jika dibandingkan ekstrak $100 \mathrm{mg} / \mathrm{kgBB}$

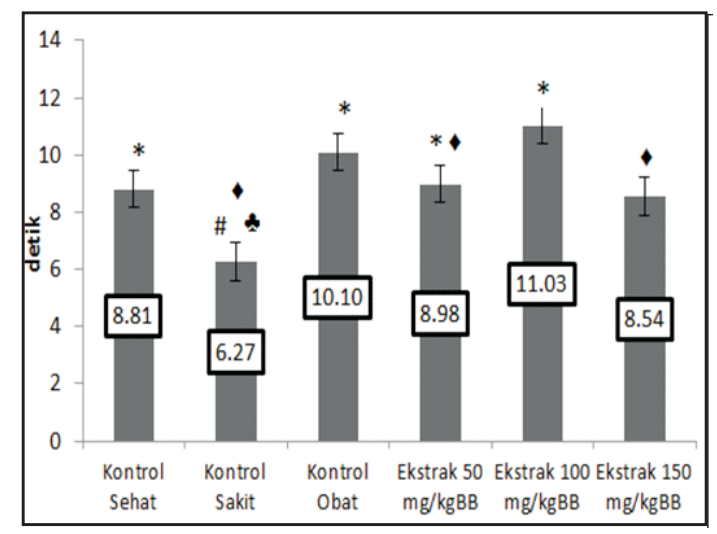

Gambar 4. Rerata waktu lamanya tikus di kuadran platform \pm SEM pada probe trial.* menunjukan $p=<0,05$ jika dibandingkan kontrol sakit, \# jika dibandingkan kontrol sehat, dan * jika dibandingkan kontrol obat

Rao et al. (2002), yang menunjukan bahwa citicoline dapat mengembalikan aktivitas asetilkolines- terase dan pompa $\mathrm{Na}^{+} / \mathrm{K}^{+}$hipokampus sehingga dapat meningkatkan performa memori.

Kelompok kontrol sakit dibandingkan dengan kelompok ekstrak dosis $100 \mathrm{mg} / \mathrm{kgBB}$ terdapat perbedaan bermakna (lihat Gambar 3).Hal ini menunjukan pemberian ekstrak etanol rimpang temulawak dosis $100 \mathrm{mg} / \mathrm{kgBB}$ dapat meningkatkan memori spasial pada tikus model demensia yang diinduksi TMT. Selain itu tidak terdapat perbedaan bermakna antara kelompok kontrol obat dengan kelompok ekstrak dosis $100 \mathrm{mg} / \mathrm{kgBB}$. Tetapi pada Gambar 4 antara kelompok kontrol sakit dengan kelompok ekstrak dosis 50 dan $100 \mathrm{mg} / \mathrm{kgBB}$ terdapat perbedaan yang bermakna.Hal ini menunjukan bahwa sebenarnya pemberian ekstrak etanol rimpang temulawak dosis $50 \mathrm{mg} / \mathrm{kg}$ BB dapat meningkatkan memori spasial tikus model demensia yang diinduksi TMT, tetapi efeknya tidak sebaik dosis $100 \mathrm{mg} / \mathrm{kgBB}$.
Jika kontrol obat dibandingkan dengan kelompok ekstrak, baik dosis $50 \mathrm{mg} / \mathrm{kgBB}, 100 \mathrm{mg} / \mathrm{kgBB}$, maupun $150 \mathrm{mg} / \mathrm{kgBB}$ tidak terdapat perbedaan bermakna. Ini menunjukan bahwa sebenarnya pemberian ekstrak etanol rimpang temulawak dengan dosis $50 \mathrm{mg} / \mathrm{kgBB}, 100 \mathrm{mg} / \mathrm{kgBB}$ dan $150 \mathrm{mg} / \mathrm{kgBB}$ dapat meningkatkan memori spasial sama seperti citicoline sebagai obat pembanding, tetapi terdapat perbedaan pada tingkat keefektifannya.

Uji Morris water maze (MWM) yang terakhir adalah uji kemampuan sensorimotoris. Uji ini hanya akan digunakan untuk melihat kemampuan tikus dalam berenang atau kemampuan motoris tikus, kemampuan indra penglihatannya sebagai kemampuan sensoris, dan motivasi tikus untuk keluar dari air sebagai faktor yang akan mempengaruhi kecepatan berenang tikus sehingga tidak akan menggambarkan kemampuan belajar maupun fungsi memori spasial tikus karena tikus tidak harus mencari dan mengingat letak platform tetapi cukup melihat tanda untuk bisa menemukan posisi platform (Vorhees dan Williams, 2006). Hasil uji menunjukan bahwa tidak ada gangguan aktivitas sensorimotoris pada hewan uji karena semua hewan uji dapat mencapai platform sebelum waktu yang ditentukan habis.

Dari hasil uji MWM terutama acquisition trial dan probe trial dapat diketahui bahwa trimethyltin chloride (TMT) dapat digunakan sebagai induktor model demensia yang menyebabkan terjadinya gangguan fungsi memori. Pemberian ekstrak etanol rimpang temulawak dengan dosis $100 \mathrm{mg} / \mathrm{kgBB}$ dapat meningkatkan memori spasial tikus model demensia yang diinduksi TMT sehingga dapat digunakan sebagai obat alternatif anti demensia yang efektifitasnya hampir sama dengan citicoline sebagai obat pembanding.

\section{KESIMPULAN}

Ekstrak etanol rimpang temulawak Curcuma xanthorrhiza, Roxb dapat meningkatkan memori spasial tikus model demensia yang diinduksi TMT. Ekstrak etanol rimpang temulawak dengandosis 100 $\mathrm{mg} / \mathrm{kgBB}$ dapat meningkatkan memori spasial tikus model demensia yang diinduksi TMT.

\section{DAFTAR PUSTAKA}

Bala, K., Tripathy, B.C., Sharma, D., 2006, Neuroprotective and anti-ageing effects of curcumin in aged rat brain region, Biogerontology, 7:81-9.

Balaban, C.D., O'Callaghan, J.P., Billingsley, M.I., 1988, Trimethyltin-induced Neuronal Damage in the Rat Brain, Neuroscience, 26: 337-361. 
Butterfield, D.A., Griffin, S., Munch, G., Pasinetti, G.M., 2002, Amyloid $\beta$-peptide and amyloid pathology are central to the oxidative stres and inflammatory cascades under which Alzheimer's disease brain exists, J. Alzheimers Dis., 4 (3): 193 -201.

Cole, G.M., Morihara, T., Lim, G.P., Yang, F., Begum, A., Frautschy, S.A., 2004, NSAID and Antioxidant Prevention of Alzheimer's disease: Lessons from In Vitro and Animal Models. Ann. N. Y. Acad. Sci., 1035:68-84.

Dogru, E.J., Gumusbas,U., Kara, F., 2003, Individual variation in the spatial reference and working memory assased under allothetic and idiothetic orientation cues in rat, Acta Neurobiologica, 63:17-23.

Evans, C., Mellor-Clark, J., Margison, F., Barkham, M., Audin, K., Connell, J., McGrath, G., 2000, CORE: Clinical Outcomes in Routine Evaluation, Journal of Mental Health, 9: 247-255.

Geloso, M.C., Corvino, V., Cavallo, V., Toesca, A., Guadagni, E., Passalacqua, R., Micheti, F., 2004, Expression of Astrocytic Nestin in the Rat Hippocampus During Trimethyltin-induced neurodegeneration, Neuroci Lett, 357: 103-106.

Guyton,A.C., Hall, J.E., 2000, The Cerebral cortex; Intellectual functions of the brain: Learning and memory, Textbook of Medical Physiology, $10^{\text {th }}$ edition, Philadelphia.

Khopde, S.M., Priyadarsini, K.I, Venkatesan, N., Rao, M.N.A., 1999, Free radical scavenging ability and antioxidant efficiency of curcumin and its substituted analogue. Biophysical Chemistry, 80(2): 83-89.

Ishikawa, K., Kubo, T., Shibanoki, S., Matsumoto, A., Hata, H., Asai, S., 1997, Hippocampal degeneration inducing impairment of learning in rats: model of dementia, Behav. Brain Res., 83: 39-44.

Park, H.J., Shim, S.S., Choi, W.K., Kim, K.S., Shim, I.S., 2011, Neuroprotective Effect of Lucium chinense Fruit on Trimethyltin Induced Learning and Memory Deficits in the Rats, Exp Neurobiol, 20(3): 137-143.

Rao, M.A., Hatcher, J.F., Dempsey, R.J., 2002, Citicoline: neuroprotective mechanisms in cerebral ischemia, Journal of Neurochemistry, 80: $12 \pm 23$.

Ringman, J.M., Sally, A.F., Gregory M.C., Donna, L.M., Jeffrey, L.C., 2005, A Potential Role of the Curry Spice Curcumin in Alzheimer's Disease, Curr Alzheimer Res., 2(2): 131-136.

Shuto, M., Higuchi, K., Sugiyama, C., Yoneyama, M., Kuramoto, N., Nagashima, R., Kawada, K., Ogita, K., 2009, Endogenous and Exogenous Glucocorticoids Prevent Trimethyltin From Causing Neuronal Degeneration of the Mouse Brain In Vivo: Involvement of Oxidative Stres Pathways, J Pharmacol Sci, 110: 424-436.

van Marum R.J., 2008, Current and future therapy in Alzheimer's disease, Fundam. Clin. Pharmacol, 22, 265-274.

Vorhees, Charles V., Williams, Michael T., 2006, Morris water maze: procedures for assessing spatial and related forms of learning and memory, Nat Protoc., 1 (2): 848-858.

Zhang, L., Li, L., Prabhakaran, K., Borowitz, J.L., Isom, G.E., 2006, Trimethyltin induced apoptosis is associated with upregulation of inducible nitric oxide synthase and bax in a hippocampal cell line, Toxicol. Appl. Pharmacol, 216, 34-43. 